\title{
Changing School Demographies - Asking Teachers about Their Training Needs in Intercultural Education: A case Study in Greece
}

\author{
Eugenia A. Panitsides ${ }^{1} \&$ Aliki Vlachou ${ }^{2}$ \\ ${ }^{1}$ Adjunct Faculty, Hellenic Open University, Greece \\ ${ }^{2}$ Post-graduate student, Hellenic Open University, Greece \\ Correspondence: Eugenia A. Panitsides, Adjunct Faculty, Hellenic Open University, 18 Aristotelous str, 26335 Patras, \\ Greece. E-mail: epantsidou@uom.gr
}

Received: December 11, 2017 Accepted: December 27, 2017 Online Published: January 12, 2018

doi:10.5539/res.v10n1p34 URL: https://doi.org/10.5539/res.v10n1p34

\begin{abstract}
In Greece, since 2015, when immigrant flows increased due to the crisis in Syria, there have been significant changes in school demographics, raising concerns as to whether in-service teachers possess the competences necessary to meet the upcoming challenges. We therefore investigated the views of Primary Education teachers, regarding their needs in intercultural education, and the parameters they deem important in implementing effective training interventions. The statistical analysis of the data revealed the necessity of implementing training interventions aligned with teachers' individual needs, whilst there have been identified several issues regarding the existing training schemes, which demand serious consideration and further investigation.
\end{abstract}

Keywords: In-service teacher training, Intercultural education, Intercultural competence, Training needs, Quantitative research. Immigrants

\section{Introduction}

Schools nowadays increasingly accommodate students from diverse racial, linguistic, and cultural backgrounds (Bifuh-Ambe, 2006; Hachfeld et al., 2015; MacPherson, 2010). This raises expectations for teachers who should possess the intercultural skills demanded to address the humanitarian mandates innate in their role, that is, to assist all learners reach well-being through education.

It is indeed teachers' beliefs towards multiculturalism that significantly influence how they plan, organise, and implement their lessons, how responsive they are to their students, but also how self-efficient and motivated they feel in their job (Grimminger, 2011; Hachfeld et al., 2015; Horenczyk \& Tatar, 2002). The sought after intercultural competence development is thus inherently intertwined with certain attitudinal transformations. In specific, in order to address the culture gap and meet the educational needs of diverse students in the classes, teachers they (it must be removed) must be culturally conscious and interculturally sensitive (MacPherson, 2010; Marx \& Moss, 2011).

It is primarily for Higher Education Institutions to build curricula that provide preservice teachers with the critical competences necessary to respond to the intellectual, social, and personal developmental needs of diverse learners in the classrooms (Baldwin et al., 2007; Bifuh-Ambe, 2006; Paul-Binyamin \& Reingold, 2014). However, does this alone suffice? Among the swiftly changing school demographics, are teachers upon graduation equipped with the competences demanded to effectively meet all the upcoming challenges when they enter the profession? There is, thus, rising concern as to whether in-service teachers are equipped with the intercultural competence demanded to meet the overwhelming challenges brought about by the changing circumstances. In this regard, systematic professional development of teaching practitioners has come to the fore as a signpost for effective schools, with teacher training programmes systematically implemented globally to foster an intercultural, inclusive educational approach (Leeman, 2006; Sales, Traver \& García, 2011; Papastamatis et. al., 2009).

As far as Greece is concerned however, there has been evidence that the educational system is not meeting the needs of many of immigrant and/or minority origin students, whilst much of the in-service training in intercultural education has been fragmented or inadequate (Magos, 2007; Xohellis, 2002). We deemed thus important to conduct an exploratory study in order to investigate the views of Primary Education teachers, as regards their training needs in intercultural education, as well as the parameters they consider crucial in the design and implementation of effective in-service training schemata, so as to formulate a comprehensive proposal for a training programme based on trainees' recorded needs and 
suggestions.

\section{The Context}

\subsection{New Demographies in Greek Schools}

As discussed above, due to the steady increase of migration, the number of students who are found to be of an ethnic and/or cultural minority in the classrooms is on the rise globally (Bifuh-Ambe, 2006; Hachfeld et al., 2015; MacPherson, 2010). Especially in Greece, since 2015, when immigrant flows abruptly increased due to the climaxing crisis in Syria, changes in school demography have been indeed spurring. Actually, there has been a significant increase since the 1980s in the inflows of immigrants in Greece (Doikou \& Diamandidou, 2011). However, the phenomenon has escalated during the recent years with the influx of immigrants and refugees from the middle-east, in their majority lacking any legal documents. In search of optimal prospects, they regard Greece as a stopover in making their way to other European countries (Georgiopoulou \& Souliotis, 2016). Yet, the status quo of closed borders compels them to remain in the country for an undetermined period of time. Furthermore, the situation becomes even more challenging, considering the fact that numbers are not easily determined, as the influx continues.

The Greek government is thus confronted with an overwhelming situation amidst the ongoing economic crisis and particularly restricted resources. According to the official discourses of the Ministry of Education (2016), the Greek education system will take all necessary actions so as to effectively integrate immigrant and refugee students. From this standpoint, education is assigned a leading role in alleviating social problems, whilst foster a sense of social justice (Clay \& George, 2000; Dooly \& Villanueva, 2006; Field, Kuczera \& Pont, 2007 Pitkänen, Verma, \& Kalekin-Fishman, 2002).

Student population heterogeneity and cultural background variation dictated by the new demography of rising percentages of students of immigrant and/or refugee origin in the classes clearly intensifies the challenge and the complexities inherent in teaching (Magos, 2006). Not to mention that there is a great deal of diversity within an ethnic group itself, whilst students may also have different skills in adapting to the host country and the effect of ethnicity may vary from student to student (den Brok \& Levy, 2005).

Teachers thus, being undeniably the key actors in the educational process, should cater for the management of any cultural differences in their classes, and advance intercultural communication and reciprocity. Most importantly however they need to ceaselessly adjust to the new realities emerging, not only in schools, but in the wider socio-cultural context (Darling \& Hammond, 2006). In this respect, implementing professional development interventions that encourage transformation in schools towards an intercultural, inclusive educational approach, is largely considered a valuable determinant (Leeman, 2006; Sales, Traver \& García, 2011).

\subsection{Professional Development Programmes Among Changing Demographics}

With the world turning into a global village, judging other cultures using one's own culture as the norm largely fuels cultural prejudice, misunderstanding, and discrimination. Especially within the contemporary school microcosm, wherein teachers are constantly bound to deal with "otherness", ethic, cultural or other, it is a mandate to possess the skills and dispositions necessary to address the stereotypes that differentiate individuals (Baldwin, Buchanan \& Rudisill, 2007; Grimminger, 2011; Kambutu \& Nganga, 2008). However, praxis is not commonly congruent with theory. Most often teachers' stereotypical projections and uninformed interpretations lead to dealing with differences with prejudice, in a completely inappropriate way or, even worse, just ignore them (Magos, 2006, 2007). In effect, education has been indicated to have a persistent history of representing the dominant group, thus further subordinating already marginalised groups (Baldwin et al., 2007). According to den Brok and Levy (2005), teacher interpersonal behaviour has an absolutely determining role to play in intercultural education, being more significant for immigrant minority students' outcomes than for their indigenous peers.

An eminent issue thus remains whether in-service teachers are equipped with the competences necessary to effectively tackle the complexities of the evolving school demographics. It is widely accepted that no matter the preparation preservice teachers may have received during their university studies, it largely fails to grasp the complexities inherent in teaching multicultural classes (Kambutu \& Nganga, 2008). To develop the essential cultural awareness, understanding and appreciation is apparently a process that builds with experience. We should always bear in mind that becoming an effective teaching professional is a journey, not a destination (Papastamatis et al., 2009). To this end, engaging in in-service training that focuses on ways of dealing with ethnic, cultural and other kinds of otherness in a school class is essential, in order teachers to become culturally responsive (Magos, 2007).

Effective intercultural education training programmes should therefore enable participants to confront their ethnocentric worldviews and reflect on their attitudes toward student diversity, facilitating them to become aware of the ways culture influences teaching and learning (Marx \& Moss, 2011; Yang \& Montgomery, 2013). This begins with an understanding of their perception of cultural difference and recognition of their students' vast diversity of experience, cultural background 
and perspectives on learning (Yuen, 2010).

Recent studies (Baldwin et al., 2007; Penga \& Wu, 2016; Shapira-Lishchinsky, 2016) have indicated that implementing training interventions which draw on social justice, reflective practice and intercultural contact, both direct and indirect, may be beneficial for teaching staff's efficient growth and fruitful adaptation to the new regularities formed under the changing circumstances. They can actually positively affect participants' dispositions toward teaching in diverse settings and provide them with the possibility of exploring novel strategies to deal with the challenges encountered in culturally pluralistic classes. This however entails the introduction of a more sophisticated cognitive framework that will help teachers re-examine their assumptions. In effect, having trainees engage in self-reflection is a necessary starting point for developing ethno-relative orientation to diversity, cultural sensitivity and an integrated worldview (MacPherson, 2010; Rissanen, Kuusisto \& Kuusisto, 2016; Yuen, 2010).

Another critical challenge for in-service teacher training programmes is to work harder to integrate the theory with the practical realities of classes and schools, so as to encourage overall school culture progress towards an intercultural and inclusive approach, putting students back at the center of education and addressing their subjective and objective cultural needs. (Dooly \& Villanueva, 2006; Sales et al., 2011; Schoorman \& Bogotch, 2010). This cannot though be accomplished by ignoring realities at the societal level too, especially considering that there is a great deal of diversity within ethnic groups themselves (den Brok \& Levy, 2005; Horenczyk \& Tatar, 2002).

Teachers' individual and collective training needs may thus markedly vary, making it important to have their views to recorded and taken into account in the design and implementation of any training intervention (Pellicer \& Anderson, 1995). In general, until nowadays, professional development programmes in Greece have failed to reach teachers' needs while they often run randomly and uncoordinatedly. In most cases, in-service training has been drawing on correcting or modifying deficiencies, whilst teachers have often been excluded from any meaningful participation in planning and implementation of training programmes (Papastamatis et al., 2009).

In detail, professional development for in-service teachers in Greece has been provided through various bodies, the leading among which are Regional Training Centers, Higher Education Institutions, School Advisors and Scientific Associations. However, most training interventions so far have been deemed fragmented or deficient. Relevant studies in Greece (Charitos, 2011; Magos, 2007; Xohellis, 2002) have indicated a positive disposition of in-service teachers towards their participation in training programmes. At the same time though, there have been identified weighty shortcomings in the training programmes provided, mostly related to issues of quality, discontinuance, unrelatedness, and lack of interconnection between theory and practice (Papastamatis et al., 2009). In fact, similar weaknesses have been reported internationally, as traditional programme models have been found to be mostly collections of largely unrelated courses, employing pedagogies that fail to link theory and practice (Darling-Hammond, 2006).

However, against the backdrop of changing demographics in classrooms and in local societies, it is now more than ever critical to have teachers' views and experiences considered in determining how, when, where and what in-service training programmes need to be delivered. It was thus deemed important to ask primary education teachers: a) whether they consider it necessary to attend training programmes in intercultural education, b) what should be the content of such programmes and c) how they could be implemented. To meet the aims in this study, the research approach adopted was that of a 'case study. According to Merriam (2001), the researcher needs to select a case or sample from which the most can be learned. Thus, the Viotia Prefecture was selected wherein teachers, due to the establishment of a Hotspot in the area $^{1}$, were called to accommodate a significant number of immigrant or refugee students in their classes ${ }^{2}$

\section{The Study: Methods \& Tools}

\subsection{Aims and Scope}

In light of the above assumptions, an exploratory quantitative study was conducted with a random sample of Primary Education teachers drawn from schools in Viotia Prefecture in Greece, with the aim to record participants' perceived views on their training needs in intercultural education, as well as the parameters they deem important in designing and implementing effective training interventions.

Precisely, the questions guiding this study have been:

- What is the current situation as regards respondents' participation in training interventions in intercultural education?

\footnotetext{
${ }^{1}$ a Hotspot is a EU-run reception center in frontline member states like Italy and Greece to identify and fingerprint migrants and refugees.

2 The immigrant students enrolled in primary schools in Viotia during the school year 2015-2016 were 650 with a total pupil population of 8,550 pupils.
} 
- What are respondents' perceived views on the necessity to attend training programmes in intercultural education?

- What are respondents' perceived views on the content of training programmes in intercultural education?

- What are respondents' perceived views on the critical aspects of an effective training programme?

3.2 Sample

The study was conducted with a sample drawn from primary education teachers in Viotia Prefecture in Greece, as lately they have been confronted with a sudden turnaround in the demography of their classes. Sampling was conducted in two stages. The first stage involved the selection of school units by random sampling, drawn from the complete lists provided by the Primary Education Directorate of Viotia, whilst the second stage comprised the selection of teachers by stratified sampling based on gender and experience in public education, so that both variables would be substantially represented.

The sample size was calculated following Cohen's approach using G*Power software. At significance level 0.05, level of power 0.80 , expected effect size 0.80 , and 4:1 ratio of the two subgroups in comparison (the ratio was set in relation to gender ${ }^{3}$ ), the sample size was determined to comprise 84 teachers. Thus, our sample eventually consisted of 17 school units ( 9 schools in the Thebes region and 8 schools in the Livadia region), in a total of 150 schools in the Prefecture, whilst the questionnaires were administered on site to 110 teachers (out of a total of approximately 1000 teachers serving in primary schools in Viotia) to ensure the minimum demanded number of valid questionnaires.

\subsection{Measures}

To conduct the study a questionnaire was developed, designed to reflect the context, aims and limitations of the specific study. In detail, the questionnaire constructed, was structured in two sections: the first comprised demographic data, whilst the second consisted of 10 factors, each one of them comprising a set of closed items/statements, these being less time consuming and eliciting objective responses.

In the first 6 factors the questions were expressed in the form of statements asking participants to indicate their degree of agreement or disagreement on a four-point Likert scale format, whilst in the four remaining factors questions were in the form of hierarchies requesting respondents to rank items in order of importance. Furthermore, two open ended questions were included, allowing for open-ended comments, so that more spontaneous answers could be elicited too ${ }^{4}$.

The questions included in the questionnaire were grounded on relevant literature (Doikou \& Diamandidou, 2011; Charitos, 2011; Dooly \& Villanueva, 2007; Magos, 2006, 2007; Papastamatis et al., 2009; Penga \& Wu, 2016; Sales et al., 2011; Schoorman \& Bogotch, 2010; Xohellis, 2002; Yuen, 2010), as well as prior discussions/open-ended interviews with in-service teachers.

The questionnaire was initially administered to 10 teachers serving in the region, not included in the sample. The reactions of the respondents were recorded upon their consent. The overall response to the questionnaire was quite positive, eliciting favourable comments regarding the functionality of the construction and the clarity of the questions. The research was conducted from February to March 2016.

A limitation to this study worth reiterating is the fact that the research was conducted in a very specific sociocultural context. Furthermore, the results of the study are limited by the sample size and the fact that rely solely on the subjective views of the respondents.

\subsection{Statistical Analysis}

All analyses were conducted using SPSS (Version 19). The data initially underwent analysis by descriptive statistical methods, constructing frequency distribution charts. Teachers' views were compared based on demographics and whether or not the respondents had received any training in intercultural education. For comparisons between two groups the Mann-Whitney test was applied, whilst for multiple comparisons the Kruskal-Wallis test with Mann-Whitney post hoc tests were used. On a second level, respondents were grouped based on their perceived views on the time, duration, venue and implementation bodies of an effective training programme in Intercultural Education. To conduct cluster analysis the two-step cluster algorithm was applied.

The significance level of all statistical tests was predetermined at 0.05 .

\section{Results}

\subsection{Respondents' Profile}

\footnotetext{
${ }^{3}$ In the lists of in-service teachers provided by the Primary Education Directorate of Voiotia, it was depicted that $80 \%$ of teachers are female.

${ }^{4}$ The data from the open-ended questions were analysed and quantified.
} 
The majority of participants in the sample (Table 1) were women (77.3\%), in their thirties (33.6\%). Most of them, were pretty novice teachers, having less than ten years of service in public education (44.5\%). A considerable percentage though were more experienced, having already served in public schools from eleven to twenty years (37.3\%). The vast majority of respondents were serving in large schools (with 12 or more teachers) (68.2\%), mostly located in urban areas $(80 \%)$.

Table 1. Profile of participants in the sample

\begin{tabular}{llll}
\hline $\begin{array}{l}\text { Demographic } \\
\text { characteristics }\end{array}$ & Profile & n & \% \\
\hline Sex & Female & 85 & 77.3 \\
Age & $31-40$ & 37 & 33.6 \\
& $41-50$ & 35 & 31.8 \\
Service in public education & Less than 10 years & 49 & 44.5 \\
& 11-20 years & 41 & 37.3 \\
Size of school & Large schools (with 12 or more teachers) & 75 & 68.2 \\
School area & Urban & 88 & 80.0 \\
\hline
\end{tabular}

It should be noted that the above findings are fully representative of the teachers population in Viotia Prefecture, being in compliance with the statistical data on teachers and schools provided by the Viotia Primary Education Directorate.

\subsection{Prior Training}

As regards the educational background of the respondents only 15 teachers (13.6\%) possessed a postgraduate degree, whilst none of them had a $\mathrm{PhD}$. However, a significant percentage $(52.7 \%)$ reported that they had attended training programmes in the past. Among the factors that necessitated participation in training programmes were reported to be a) the need to get familiarised with new learning and teaching methods $(97.1 \%)^{5}$, b) the concern for professional development (94.3\%), and c) the interest in the contents of the training intervention (93.5\%). Actually, the thematic area which mostly attracted the preference of participants for future training was classroom management (93.6\%), followed by new teaching methods (90.4), and use of new technologies (86.5).

As far as prior training in Intercultural Education is concerned, approximately half of the respondents (45.5\%) reported that they had attended relevant training programmes. They largely consider their attendance quite helpful (Table 2), as it enabled them to acquire new knowledge and skills (80\%), whilst they tend to favourably judge the trainers $(72 \%)$, the content $(68 \%)$ and the overall organisation $(62 \%)$ of the programmes. On the other hand, those teachers in the sample that did not attend any training courses in intercultural education (55.5\%), acknowledge the importance of training, reporting that this was mainly due to the absence of any relevant courses held in the region they were serving in (57.4\%).

Table 2. Evaluation of the Intercultural Education training programmes attended

\begin{tabular}{|c|c|c|c|c|c|c|}
\hline & $\begin{array}{l}\text { Strongly } \\
\text { agree }\end{array}$ & Agree & $\begin{array}{l}\text { Neither } \\
\text { agree, } \\
\text { disagree }\end{array}$ & nor & $\begin{array}{l}\text { Disagre } \\
e\end{array}$ & $n$ \\
\hline New knowledge and skills & $\begin{array}{l}12 \\
(24,0 \%)\end{array}$ & $\begin{array}{l}28 \\
(56,0 \%)\end{array}$ & $\begin{array}{l}9 \\
(18,0 \%)\end{array}$ & & $\begin{array}{l}1 \\
(2,0 \%)\end{array}$ & $\begin{array}{l}50 \\
(100 \%)\end{array}$ \\
\hline Trainers' expertise in the field & $\begin{array}{l}8 \\
(16,0 \%)\end{array}$ & $\begin{array}{l}28 \\
(56,0 \%)\end{array}$ & $\begin{array}{l}14 \\
(28,0 \%)\end{array}$ & & $\begin{array}{l}0 \\
(0 \%)\end{array}$ & $\begin{array}{l}50 \\
(100 \%)\end{array}$ \\
\hline Content and methods used & $\begin{array}{l}7 \\
(14,0 \%)\end{array}$ & $\begin{array}{l}27 \\
(54,0 \%)\end{array}$ & $\begin{array}{l}13 \\
(26,0 \%)\end{array}$ & & $\begin{array}{l}3 \\
(6,0 \%)\end{array}$ & $\begin{array}{l}50 \\
(100 \%)\end{array}$ \\
\hline Overall organisation (e.g. venue, & 8 & 23 & 18 & & 1 & 50 \\
\hline
\end{tabular}

\footnotetext{
${ }^{5}$ Strongly agree and Agree answers are combined for all percentages displayed.
} 


\begin{tabular}{llllll} 
equipment, accessibility etc. $)$ & $(16,0 \%)$ & $(46,0 \%)$ & $(36,0 \%)$ & $(2,0 \%)$ & $(100 \%)$ \\
\hline
\end{tabular}

(space)

\subsection{The Proposed Training Programme}

In line with respondents' perceived views on the critical aspects of an effective training programme in intercultural education aligned with their needs, the following parameters were identified (Tables $3 a$ and $3 b$ ).

As regards the training context, respondents were mostly inclined ("strongly agree" or "agree") towards attending training interventions that grant them the right to abstain from their duties (84.6\%). A significant percentage $(77.4 \%)$ opted for school-based training, but within working hours ${ }^{6}$. Furthermore, teachers seem to favour the implementation of periodical training, such as in the case of setting specific training periods per school year $(81.1 \%)$.

Relating to the duration of an effective training programme respondents tend to value more short-term (e.g. one/two-day) programmes $(66,6 \%)$, followed by medium-term ones (e.g. one/three-month) $(61,9 \%)$. However, long-term programmes (e.g. of annual duration) attracted substantial preference $(52,4 \%)$, too. Concerning the venue, the school unit $(93.4 \%)$ was indicated as the most appropriate place to facilitate participation, followed by the Directorate of Primary Education (72.7\%). Distance learning came last among participants' preferences (60.8).

Concerning the question who should be the providers/organisers of the training programmes to ensure the quality and effectiveness of the interventions, the respondents expressed a clear preference towards Pedagogical Departments (86,8\%), and Teachers' Associations (86.15\%), followed by School Counselors (63.4\%) and Regional Training Centers $(45.2 \%)$.

Table 3a. The preferred training programme in intercultural education ${ }^{7}$

\begin{tabular}{|c|c|c|c|c|c|c|}
\hline Parameters & & $\begin{array}{l}\text { Strongly } \\
\text { agree }\end{array}$ & Agree & $\begin{array}{l}\text { Neither agree, } \\
\text { nor disagree }\end{array}$ & $\begin{array}{l}\text { Disagre } \\
e\end{array}$ & $n$ \\
\hline \multirow{3}{*}{ Context } & $\begin{array}{l}\text { Be exempt from } \\
\text { teaching during training }\end{array}$ & $\begin{array}{l}54 \\
(49.1 \%)\end{array}$ & $\begin{array}{l}39 \\
(35.5 \%)\end{array}$ & $\begin{array}{l}11 \\
(10.0 \%)\end{array}$ & $\begin{array}{l}6 \\
(5.5 \%)\end{array}$ & $\begin{array}{l}110 \\
(100 \%)\end{array}$ \\
\hline & $\begin{array}{l}\text { School-based training } \\
\text { (within working hours) }\end{array}$ & $\begin{array}{l}41 \\
(38.3 \%)\end{array}$ & $\begin{array}{l}39 \\
(36.4 \%)\end{array}$ & $\begin{array}{l}23 \\
(21.5 \%)\end{array}$ & $\begin{array}{l}4 \\
(3.7 \%)\end{array}$ & $\begin{array}{l}107 \\
(100 \%)\end{array}$ \\
\hline & $\begin{array}{l}\text { Implement periodical } \\
\text { training }\end{array}$ & $\begin{array}{l}44 \\
(41.5 \%)\end{array}$ & $\begin{array}{l}42 \\
(39.6 \%)\end{array}$ & $\begin{array}{l}13 \\
(12.3 \%)\end{array}$ & $\begin{array}{l}7 \\
(6.6 \%)\end{array}$ & $\begin{array}{l}106 \\
(100 \%)\end{array}$ \\
\hline \multirow{3}{*}{ Duration } & Short-term & $\begin{array}{l}20 \\
(19.0 \%)\end{array}$ & $\begin{array}{l}30 \\
(47.6 \%)\end{array}$ & $\begin{array}{l}30 \\
(28.6 \%)\end{array}$ & $\begin{array}{l}5 \\
(4.8 \%)\end{array}$ & $\begin{array}{l}105 \\
(100 \%)\end{array}$ \\
\hline & Medium-term & $\begin{array}{l}27 \\
(25.7 \%)\end{array}$ & $\begin{array}{l}38 \\
(36.2 \%)\end{array}$ & $\begin{array}{l}28 \\
(26.7 \%)\end{array}$ & $\begin{array}{l}12 \\
(11.4 \%)\end{array}$ & $\begin{array}{l}105 \\
(100 \%)\end{array}$ \\
\hline & Long-term & $\begin{array}{l}23 \\
(21.9 \%)\end{array}$ & $\begin{array}{l}32 \\
(30.5 \%)\end{array}$ & $\begin{array}{l}20 \\
(19.0 \%)\end{array}$ & $\begin{array}{l}30 \\
(28.6 \%)\end{array}$ & $\begin{array}{l}105 \\
(100 \%)\end{array}$ \\
\hline \multirow{2}{*}{ Venue } & School unit & $\begin{array}{l}59 \\
(55.1 \%)\end{array}$ & $\begin{array}{l}41 \\
(38.3 \%)\end{array}$ & $\begin{array}{l}5 \\
(4.7 \%)\end{array}$ & $\begin{array}{l}2 \\
(1.9 \%)\end{array}$ & $\begin{array}{l}107 \\
(100 \%)\end{array}$ \\
\hline & Directorate of Education & $\begin{array}{l}32 \\
(30.2 \%)\end{array}$ & $\begin{array}{l}45 \\
(42.5 \%)\end{array}$ & $\begin{array}{l}25 \\
(23.6 \%)\end{array}$ & $\begin{array}{l}4 \\
(3, .8 \%)\end{array}$ & $\begin{array}{l}106 \\
(100 \%)\end{array}$ \\
\hline \multirow[t]{2}{*}{ Provider } & $\begin{array}{l}\text { Pedagogical } \\
\text { Departments }\end{array}$ & $\begin{array}{l}43 \\
(40.6 \%)\end{array}$ & $\begin{array}{l}49 \\
(46.2 \%)\end{array}$ & $\begin{array}{l}10 \\
(9.4 \%)\end{array}$ & $\begin{array}{l}4 \\
(3.8 \%)\end{array}$ & $\begin{array}{l}106 \\
(100 \%)\end{array}$ \\
\hline & Distance Learning & 30 & 31 & 26 & 15 & 102 \\
\hline
\end{tabular}

\footnotetext{
${ }^{6}$ Only $33 \%$ of respondents were in favour (strongly agree/agree) of school-based training out of working hours (e.g. soon after their shift)

${ }^{7}$ Only the items with higher scores are presented
} 


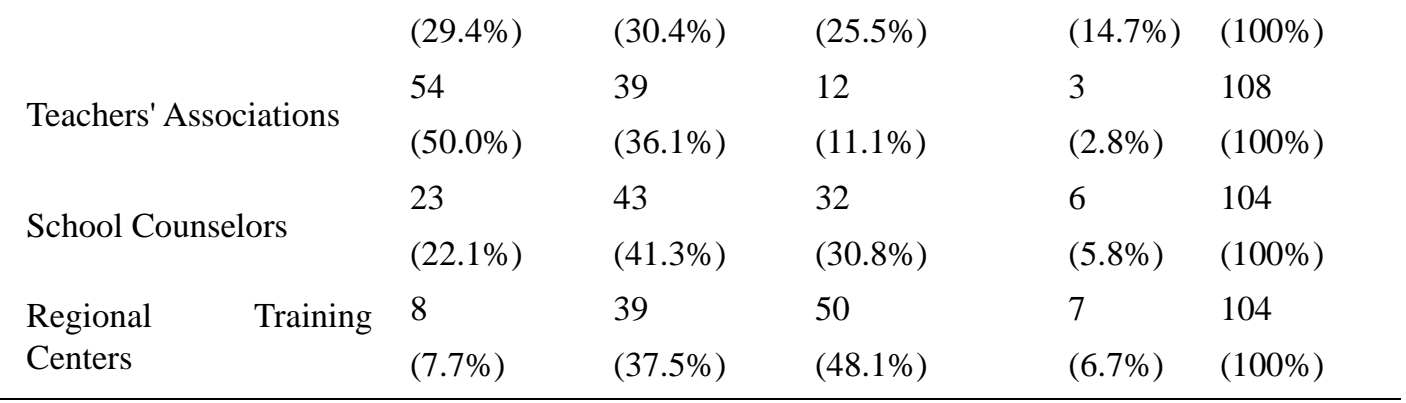

As regards the methods to be applied in delivering an intercultural education training programme, respondents ranked higher the "combined use of modern teaching methods complying with the learning object" $(2,44 \pm 1,67)^{8}$, "micro-teaching"( $2,63 \pm 1,46)$ and "combination of theory with practical application" $(2,69 \pm 1,53)$.

The thematic areas in intercultural education which respondents prioritised as necessary to receive training in, were "communication and interaction in multicultural classes" $(2.89 \pm 1.98)$, and "teaching methods in intercultural education" (3.07 \pm 1.99$)$. Participants in the study finally stated that training programmes should aim at "changing attitudes" $(2,22 \pm$ $1,42)$, "developing skills" $(2,49 \pm 1,35)$, and "fostering values" $(2,59 \pm 1.46)$, whilst the competences primarily targeted should be the "development of empathy" $(3,36 \pm 2,39)$ and "building team culture " $(3,60 \pm 2,30)$.

Table $3 \mathrm{~b}$. The preferred training programme in intercultural education ${ }^{7}$

\begin{tabular}{|c|c|c|c|c|c|c|c|}
\hline Parameters & & $\mathbf{n}$ & Mean & $\begin{array}{l}\text { St } \\
\text { deviayion }\end{array}$ & Median & $\mathbf{Q}_{1}$ & $\mathbf{Q}_{3}$ \\
\hline \multirow{3}{*}{ Methods } & $\begin{array}{l}\text { Combined use of teaching } \\
\text { methods complying with } \\
\text { the learning object }\end{array}$ & 109 & 2.44 & 1.67 & 2 & 1 & 4 \\
\hline & Micro-teaching & 110 & 2.63 & 1.46 & 2 & 1 & 4 \\
\hline & Link theory with practice & 109 & 2.69 & 1.53 & 2 & 1 & 4 \\
\hline \multirow{2}{*}{$\begin{array}{l}\text { Thematic } \\
\text { areas }\end{array}$} & $\begin{array}{l}\text { Communication and } \\
\text { interaction in multicultural } \\
\text { classes }\end{array}$ & 110 & 2.89 & 1.98 & 3 & 1 & 4 \\
\hline & $\begin{array}{l}\text { Teaching methods in } \\
\text { intercultural education }\end{array}$ & 106 & 3.07 & 1.99 & 3 & 1 & 4 \\
\hline \multirow{3}{*}{ Aims } & Change attitudes & 109 & 2.22 & 1.42 & 2 & 1 & 3 \\
\hline & Develop skills & 109 & 2.49 & 1.35 & 3 & 1 & 3 \\
\hline & Foster values & 109 & 2.59 & 1.46 & 2 & 1 & 4 \\
\hline \multirow{2}{*}{ Competences } & Develop empathy & 108 & 3.36 & 2.39 & 3 & 1 & 6 \\
\hline & Build team culture & 108 & 3.60 & 2.30 & 3 & 2 & 5 \\
\hline
\end{tabular}

Hierarchal data are presented in terms of sample size, mean, standard deviation, median, $1^{\text {st }}$ and $3^{\text {rd }}$ quadrant

\subsection{Inferential Statistical Analysis}

On a second level of analysis, it was attempted to identify the factors that differentiate respondents' views. The results revealed statistically significant correlations which enabled the grouping of respondents in three clusters, based on their perceived views on the characteristics an effective training programme in intercultural education should bear and their experience in public education. The three typologies were assigned names that reflect the overall views expressed (Table 4).

\footnotetext{
${ }^{8}$ In ranking questions Mean and Standard deviation are presented for each item
} 


\section{1 st cluster - "The Indifferent"}

The first cluster comprises mainly respondents with less than 10 years of service in public education (56.6\%). They mostly consider that any training out of working hours would be difficult to attend (71.8\%), whilst, on the contrary it would be very helpful to participate in educational interventions that grant exemption from teaching duties (76.9\%). They also argue that one-hour or two-hour seminars $(82.1 \%)$ would be far more effective than medium-term or annual training programmes. Moreover, they regard distance learning as very efficient $(61.5 \%)$, whilst they reject Regional Training Centers both as a suitable venue or provider for an effective training programme.

\section{2nd cluster "The Experienced"}

The second cluster mainly comprises respondents with more than 10 years of service in public education (11-20 years $43.8 \%$ and over 20 years $34.4 \%$ ). They also consider that out-of-working hours training would restrict participation $(87.5 \%)$, whilst they totally agree that it would be facilitating to attend interventions that grant exemption from teaching duties $(100 \%)$. However, in contrast with the previous cluster, they deem medium-term (100\%) or even long-term $(68.8 \%)$ training interventions more effective than one or two hour seminars (78.1\%). They also argue that distance learning would not actually facilitate participation, and they favour school-based training (96.9\%). Once again, they reject Regional Training Centers both as a suitable venue or provider of an effective training programme.

\section{3rd cluster "The Training fans"}

The third cluster also mainly comprises respondents with less than 10 years of service in public education. However, what differentiates them from the previous clusters is that they practically value all in-service training. In contrast with the other clusters, they think that the implementation of out-of-working hours training would be facilitating their participation (58.6\%). They also greatly opt for the introduction of periodical training (93.1), while they are in favour of long-term training programmes (93.1\%) and distance learning (96.6\%). Another substantial differentiation from the other two clusters is that they have a positive stance towards Regional Training Centers, both as a suitable venue (72.4\%) or provider of an effective training programme $(69 \%)$.

Table 4. Profile of respondents per cluster

\begin{tabular}{|c|c|c|c|c|c|c|c|}
\hline \multirow{2}{*}{\multicolumn{2}{|c|}{ Perceived views }} & \multicolumn{2}{|l|}{ 1st Cluster } & \multicolumn{2}{|l|}{$2^{\text {nd }}$ Cluster } & \multicolumn{2}{|l|}{$\mathbf{3}^{\text {rd }}$ Cluster } \\
\hline & & $\begin{array}{l}\text { Degree } \\
\text { agreement }\end{array}$ & $\%$ & $\begin{array}{l}\text { Degree } \\
\text { agreement }\end{array}$ & $\%$ & $\begin{array}{l}\text { Degree } \\
\text { agreement }\end{array}$ & $\%$ \\
\hline \multirow[t]{4}{*}{ Context } & $\begin{array}{l}\text { School-based } \\
\text { training beyond } \\
\text { working hours }\end{array}$ & $\begin{array}{l}\text { Neither agree. nor } \\
\text { disagree/Disagree }\end{array}$ & 71.8 & $\begin{array}{l}\text { Neither agree, nor } \\
\text { disagree/Disagree }\end{array}$ & 87.5 & $\begin{array}{l}\text { Strongly } \\
\text { agree/Agree }\end{array}$ & 58.6 \\
\hline & $\begin{array}{l}\text { School-based } \\
\text { training within } \\
\text { working hours }\end{array}$ & $\begin{array}{l}\text { Strongly } \\
\text { agree/Agree }\end{array}$ & 79.5 & $\begin{array}{l}\text { Strongly } \\
\text { agree/Agree }\end{array}$ & 59.4 & $\begin{array}{l}\text { Strongly } \\
\text { agree/Agree }\end{array}$ & 86.2 \\
\hline & $\begin{array}{l}\text { Attend } \\
\text { periodical } \\
\text { training }\end{array}$ & $\begin{array}{l}\text { Strongly } \\
\text { agree/Agree }\end{array}$ & 74.4 & $\begin{array}{l}\text { Strongly } \\
\text { agree/Agree }\end{array}$ & 75.0 & $\begin{array}{l}\text { Strongly } \\
\text { agree/Agree }\end{array}$ & 93.1 \\
\hline & $\begin{array}{l}\text { Be exempt from } \\
\text { duties during } \\
\text { training }\end{array}$ & $\begin{array}{l}\text { Strongly } \\
\text { agree/Agree }\end{array}$ & 76.9 & $\begin{array}{l}\text { Strongly } \\
\text { agree/Agree }\end{array}$ & 100 & $\begin{array}{l}\text { Strongly } \\
\text { agree/Agree }\end{array}$ & 72.4 \\
\hline \multirow[t]{4}{*}{ Duration } & $\begin{array}{l}\text { One or two-hour } \\
\text { seminars }\end{array}$ & $\begin{array}{l}\text { Strongly } \\
\text { agree/Agree }\end{array}$ & 82.1 & $\begin{array}{l}\text { Neither agree, nor } \\
\text { disagree/Disagree }\end{array}$ & 78.1 & $\begin{array}{l}\text { Neither agree, nor } \\
\text { disagree/Disagree }\end{array}$ & 75.9 \\
\hline & $\begin{array}{l}\text { Short-term (e.g. } \\
2 \text { days) }\end{array}$ & $\begin{array}{l}\text { Strongly } \\
\text { agree/Agree }\end{array}$ & 76.9 & $\begin{array}{l}\text { Strongly } \\
\text { agree/Agree }\end{array}$ & 59.4 & $\begin{array}{l}\text { Strongly } \\
\text { agree/Agree }\end{array}$ & 62.1 \\
\hline & $\begin{array}{l}\text { Medium-term } \\
\text { (e.g. 2-3 } \\
\text { months) }\end{array}$ & $\begin{array}{l}\text { Neither agree, nor } \\
\text { disagree/Disagree }\end{array}$ & 94.9 & $\begin{array}{l}\text { Strongly } \\
\text { agree/Agree }\end{array}$ & 100 & $\begin{array}{l}\text { Strongly } \\
\text { agree/Agree }\end{array}$ & 96.6 \\
\hline & $\begin{array}{l}\text { Long-term (e.g. } \\
1 \text { year) }\end{array}$ & $\begin{array}{l}\text { Neither agree, nor } \\
\text { disagree/Disagree }\end{array}$ & 94,9 & $\begin{array}{l}\text { Strongly } \\
\text { agree/Agree }\end{array}$ & 68,8 & $\begin{array}{l}\text { Strongly } \\
\text { agree/Agree }\end{array}$ & 93,1 \\
\hline
\end{tabular}




\begin{tabular}{|c|c|c|c|c|c|c|c|}
\hline \multirow[t]{4}{*}{ Venue } & $\begin{array}{l}\text { Distance } \\
\text { training }\end{array}$ & $\begin{array}{l}\text { Strongly } \\
\text { agree/Agree }\end{array}$ & 61.5 & $\begin{array}{l}\text { Neither agree, nor } \\
\text { disagree/Disagree }\end{array}$ & 71.9 & $\begin{array}{l}\text { Strongly } \\
\text { agree/Agree }\end{array}$ & 96.6 \\
\hline & $\begin{array}{l}\text { Regional } \\
\text { Training Centers }\end{array}$ & $\begin{array}{l}\text { Neither agree, nor } \\
\text { disagree/Disagree }\end{array}$ & 61.5 & $\begin{array}{l}\text { Neither agree, nor } \\
\text { disagree/Disagree }\end{array}$ & 59.4 & $\begin{array}{l}\text { Strongly } \\
\text { agree/Agree }\end{array}$ & 72.4 \\
\hline & School units & $\begin{array}{l}\text { Strongly } \\
\text { agree/Agree }\end{array}$ & 89.7 & $\begin{array}{l}\text { Strongly } \\
\text { agree/Agree }\end{array}$ & 96.9 & $\begin{array}{l}\text { Strongly } \\
\text { agree/Agree }\end{array}$ & 93.1 \\
\hline & $\begin{array}{l}\text { Directorates of } \\
\text { Education }\end{array}$ & $\begin{array}{l}\text { Strongly } \\
\text { agree/Agree }\end{array}$ & 56.4 & $\begin{array}{l}\text { Strongly } \\
\text { agree/Agree }\end{array}$ & 78.1 & $\begin{array}{l}\text { Strongly } \\
\text { agree/Agree }\end{array}$ & 82.8 \\
\hline \multirow[t]{4}{*}{ Providers } & $\begin{array}{l}\text { Teachers' } \\
\text { Associations }\end{array}$ & $\begin{array}{l}\text { Strongly } \\
\text { agree/Agree }\end{array}$ & 82.1 & $\begin{array}{l}\text { Strongly } \\
\text { agree/Agree }\end{array}$ & 87.5 & $\begin{array}{l}\text { Strongly } \\
\text { agree/Agree }\end{array}$ & 86.2 \\
\hline & $\begin{array}{l}\text { Regional } \\
\text { Training Centers }\end{array}$ & $\begin{array}{l}\text { Neither agree, nor } \\
\text { disagree/Disagree }\end{array}$ & 69.2 & $\begin{array}{l}\text { Neither agree, nor } \\
\text { disagree/Disagree }\end{array}$ & 62.5 & $\begin{array}{l}\text { Strongly } \\
\text { agree/Agree }\end{array}$ & 69.0 \\
\hline & $\begin{array}{l}\text { Pedagogical } \\
\text { Departments }\end{array}$ & $\begin{array}{l}\text { Strongly } \\
\text { agree/Agree }\end{array}$ & 82.1 & $\begin{array}{l}\text { Strongly } \\
\text { agree/Agree }\end{array}$ & 84.4 & $\begin{array}{l}\text { Strongly } \\
\text { agree/Agree }\end{array}$ & 93.1 \\
\hline & $\begin{array}{l}\text { School } \\
\text { Counselors }\end{array}$ & $\begin{array}{l}\text { Strongly } \\
\text { agree/Agree }\end{array}$ & 64.1 & $\begin{array}{l}\text { Strongly } \\
\text { agree/Agree }\end{array}$ & 53.1 & $\begin{array}{l}\text { Strongly } \\
\text { agree/Agree v }\end{array}$ & 72.4 \\
\hline \multirow[t]{3}{*}{ Experience } & \multirow{3}{*}{$\begin{array}{l}\text { Years of service } \\
\text { in public } \\
\text { education }\end{array}$} & Less than 10 & 56.4 & Less than 10 & 21.9 & Less than 10 & 65.5 \\
\hline & & $11-20$ & 38.5 & $11-20$ & 43.8 & $11-20$ & 24.1 \\
\hline & & More than 20 & 5.1 & More than 20 & 34.4 & More than 20 & 10.3 \\
\hline
\end{tabular}

\section{Discussion}

The results of our study are largely congruent with relevant literature (Doikou \& Diamandidou, 2011; Grimminger, 2011; Magos, 2006, 2007; Penga \& Wu, 2016; Sales et al., 2011; Yuen, 2010). Following the wider the feminisation trend of the teaching profession, the majority of teachers in our study were women. They mostly belonged to the 31-40 age group, with less than 10 years of service in public education. Many of them may have thus been in their "survival stage" (Papastamatis et al., 2009), mainly concerned with their interpersonal adequacy, worrying about classroom control. This might explain the inclination revealed towards increased training needs in classroom management issues, in which moreover there was identified a statistically significant difference with women being more keen on the topic.

What is worth noticing, is that the educational background of the majority of participants in the study is limited to the basic university degree required for the appointment in public education. Only a low percentage of respondents had a postgraduate degree. This however contradicts the fact that respondents in the first cluster seem rather unwilling to attend training courses beyond their working hours or for longer periods, although they are mostly novice teachers, which should be further investigated in future research. Is it related to the fact that they have relatively recently graduated from Education Departments, which have lately widely incorporated intercultural education in their curricula (Dervin, 2015)? Is it because they feel frustrated by the realities of the profession they have followed, due to poor salaries, complexities of daily practice etc.? Whatever the answer, it is a finding worth shedding some light on.

It is encouraging though that approximately half of the participants had attended training programmes in intercultural education. Overall, respondents tend to have a positive stance towards former training interventions attended, in line with relative research (Doikou \& Diamandidou, 2011; Magos, 2007). However, more than half of the participants in the study stated that they had not attended any training in Intercultural education, due to the absence of such programmes in their region of service. Our findings come in line with similar studies in Greece (Papastamatis et al., 2009; Xohellis, 2002), positing that existing training programmes often run randomly and uncoordinatedly. It is also noteworthy that Regional Training Centers, one of the fundamental teacher training Institutions in Greece, were considered by respondents inappropriate both as venues and providers to launch effective training programmes. Furthermore, our findings revealed that the institution of School Counselors, although their role is directly related to the professional development and training needs of the teachers under their supervision, does not seem to have a significant influence on the overall process. This is thus another issue that deserves to be further investigated in future research.

The absolute necessity to link theory with practice in the training programmes implemented was evident in our results too, being in line with relevant research (Darling-Hammond, 2006; Sales et al., 2011). Furthermore, there was a clear mandate for developing communication and interaction skills and fostering empathy, as depicted in other studies in the field (Doikou \& Diamandidou, 2011; Charitos, 2011; Dooly \& Villanueva, 2006). 
Actually, what was attempted in the present research was to enable teachers' views to be recorded and taken into account in the future design and implementation of training schemes in intercultural education. Their message is clear, accentuating that training does matter. However, it needs to bear certain characteristics to align with their needs and facilitate participation, both at professional and personal levels:

a) Implement teaching interventions that grant exemption from teaching duties, as well as set specific training periods per year.

b) Organise short-term (e.g. two-day) and medium-term (e.g. three-month) programmes; it is evident that teachers question the expediency of annual training schemes, as well as the efficiency of single- or two-hour training.

(c) The school unit is considered to be the most appropriate venue. In line with relevant literature (Craft 2000), the school unit is deemed to constitute the natural habitat for teacher training, aligning teaching staff needs with actual practice. It is worth noting though that in the present study, distance learning did not attract particularly high percentages of preference, which is an issue that should be further researched.

d) As far as the implementing bodies are concerned, the Pedagogical Departments in Higher Education Institutions have been selected as the most suitable providers for ensuring the quality of the interventions. It should be reiterated, that both School Counselors and Regional Training Centers, the traditional "par excellence" institutions of teacher training in Greece, have not been regarded by respondents as trustworthy training organisers/providers, a fact which bears significant implications for education policy makers in Greece.

e) In line with relevant studies (Kambutu \& Nganga, 2008; MacPherson, 2010; Schoorman \& Bogotch, 2010; Yuen, 2010), it was indicated that the methods used in training programmes should comply with the learning object, enabling critical reflection which may inflict the attitudinal changes demanded and help participants develop empathy for their students, whilst bridge theory with practice.

Finally, what was revealed through inferential statistical analysis and should be further highlighted is that among the three clusters of respondents identified, it is the "needy" ones (respondents with less than 10 years of experience) that seem to question the value of in-service training, opting for hourly seminars, whilst declining to attend any training beyond their working hours. In effect, experienced teachers $\left(2^{\text {nd }}\right.$ cluster) seem to have a more realistic perception of the demands involved in teaching multicultural classes and the necessity of attending relevant training programmes. Novice teachers, on the other hand, either feel over self-confident and "indifferent" towards training ( $1^{\text {st }}$ cluster), or insecure and over-reliant on training ( $3{ }^{\text {rd }}$ cluster), in order to tackle the complexities inherent in teaching in multicultural settings. In any case, this is a finding that requires further research, as it may have weighty implications for both policy makers, as well as for teacher preparation curricula.

\section{Concluding Remarks}

Bearing in mind that teaching multicultural classes is a truly demanding and multi-faceted task, catering for quality in-service teacher training programmes emerges as a signpost for enhancing the performance of all children throughout the educational system (Magos, 2006; Doikou \& Diamandidou, 2011). Unquestionably, the swiftly changing demography in student populations, especially in those countries and regions that have mostly undertaken the challenge to host the refugees and immigrants from the recent middle-east crisis, raise the awareness that teachers' performance is defined by their intercultural competence (Grimminger, 2011). This is in turn dependent upon the quantity and quality of the education and training they have received, along with their individual attitudes, competences and needs.

Hence, are teachers in our study ready to tackle the upcoming challenges inherent in hosting, out of a sudden, a substantial number of immigrant students in their classes? Our findings suggest that most probably not. Many of them are rather inexperienced teachers, more than half had never received any training in intercultural education, and very few have some post-graduate degree that could enhance, to some extent, their teaching expertise. Most of them tend to question the effectiveness of the fundamental teacher training bodies in the country, whilst a considerable number seem to refrain from distance learning, perhaps due to lack of familiarity with internet technologies. What is more, a significant number of rather inexperienced teachers probably seem to lack the substantial awareness concerning the value of in-service training, opting for one or two-hour seminars only and these with exemption from their teaching duties.

Yet, our findings are limited as per sample and methods, and need to be replicated with larger samples and through combined methodological approaches. A challenge for future research would be to delve into the issues that arouse in the present study, such as unwillingness by novice teachers for substantial in-service training, reluctance to take advantage of distance learning and discarding of the traditional training bodies in the country. Furthermore, qualitative approaches may provide deeper insights into the complexity and interrelatedness of the diverse parameters that may have influenced our results. 


\section{References}

Baldwin, S. C., Buchanan, A. M., \& Rudisill, M. E. (2007). What teacher candidates learned about diversity, social justice, and themselves from service-learning experiences. Journal of Teacher Education, 58(4), 315-327. https://doi.org/10.1177/0022487107305259

Bifuh-Ambe, E. (2006). Fostering multicultural appreciation in pre-service teachers through multicultural curricular transformation. Teaching and Teacher Education, 22, 690-699. https://doi.org/10.1016/j.tate.2006.03.005

den Brok. P., \& Levy, J. (2005). Teacher-student relationships in multicultural classes: Reviewing the past, preparing the future. International Journal of Educational Research, 43, 72-88. https://doi.org/10.1016/j.ijer.2006.03.007

Charitos, B. (2011). The intercultural approach in the education of students in Pedagogical Departments (Unpublished doctoral thesis), University of Macedonia, Greece. (in Greek)

Clay, J. \& George, R. (2000). Intercultural Education: A Code of Practice for the twenty-first century. European Journal of Teacher Education, 23(2), 203-211. https://doi.org/10.1080/713667276

Craft, A. (2000). Continuing professional development: A practical guide for teachers and schools ( $2^{\text {nd }}$ edn). London: Routledge Falmer. https://doi.org/10.4324/9780203420041

Darling-Hammond, L. (2006). Constructing 21st-Century Teacher Education. Journal of Teacher Education, 57(3), 300-314. https://doi.org/10.1177/0022487105285962

Dervin, F. (2015). Towards post-intercultural teacher education: analysing 'extreme' intercultural dialogue to reconstruct interculturality. European Journal of Teacher Education, 38(1), 71-86. https://doi.org/10.1080/02619768.2014.902441

Doikou, M., \& Diamandidou, K. (2011). Enhancing teachers' counselling skills: student teachers' views on a teachers' education programme. European Journal of Teacher Education, 34(1), 61-79. https://doi.org/10.1080/02619768.2010.534979

Dooly, M and Villanueva, M. (2006). Internationalisation as a key dimension to teacher education. European Journal of Teacher Education, 29(2), 223-240. https://doi.org/10.1080/02619760600617409

Field, S., Kuczera, M., \& Pont, B. (2007). No more failures: Ten steps to equity in education. Paris: OECD Publishing. https://doi.org/10.1787/9789264032606-en

Georgopoulou, T., \& Souliotis, G. (2016, February 25). Camping of migrants across the country. Kathimerini. Retrieved from http://www.kathimerini.gr/ (in Greek)

Grimminger, E. (2011). Intercultural competence among sports and PE teachers. Theoretical foundations and empirical verification. European Journal of Teacher Education, 34(3), 317-337.

https://doi.org/10.1080/02619768.2010.546834

Hachfeld, A., Hahn, A., Schroeder, S., Anders, Y., \& Kunter, M. (2015). Should teachers be colorblind? How multicultural and egalitarian beliefs differentially relate to aspects of teachers' professional competence for teaching in diverse classrooms. Teaching and Teacher Education 48, 44-55.

https://doi.org/10.1016/j.tate.2015.02.001

Horenczyk, G., \& Tatar, M. (2002). Teachers' attitudes toward multiculturalism and their perceptions of the school organizational culture. Teaching and Teacher Education, 18, 435-445. https://doi.org/10.1016/S0742-051X(02)00008-2

Kambutu, J., \& Nganga, L.W. (2008). In these uncertain times: Educators build cultural awareness through planned international experiences. Teaching and Teacher Education, 24, 939-951.

https://doi.org/10.1016/j.tate.2007.08.008

Leeman, Y. (2006). Teaching in ethnically diverse schools: teachers' professionalism. European Journal of Teacher Education, 29(3), 341-356. https://doi.org/10.1080/02619760600795171

MacPherson, S. (2010). Teachers' collaborative conversations about culture: Negotiating decision making in intercultural teaching. Journal of Teacher Education, 61(3), 271-286. https://doi.org/10.1177/0022487109353032

Magos, K. (2006). Teachers from the majority population — pupils from the minority: Results of a research in the field of Greek minority education. European Journal of Teacher Education, 29(3), 357-369.

https://doi.org/10.1080/02619760600795189 
Magos, K. (2007). The contribution of action-research to training teachers in intercultural education: A research in the field of Greek minority education. Teaching and Teacher Education, 23, 1102-1112. https://doi.org/10.1016/j.tate.2006.09.001

Marx, H., \& Moss, D. M. (2011). Please mind the culture gap: Intercultural development during a teacher education study abroad program. Journal of Teacher Education, 62(1), 35-47. https://doi.org/10.1177/0022487110381998

Merriam, S. B. (2001). Qualitative Research and Case Study Applications in Education. San Francisco: Jossey-Bass.

Ministry of Education (2016). The Minister of Education Nikos Filis in the Founding Declaration on Refugees. Retrieved from https://www.minedu.gov.gr (in Greek).

Papastamatis, A., Panitsides, E., Giavrimis, P. \& Papanis, E. (2009). Facilitating Teachers' and Educators' Effective Professional Development. Review of European Studies, 1(2), 83-90. https://doi.org/10.5539/res.v1n2p83

Paul-Binyamin, I., \& Reingold, R. (2014). Multiculturalism in teacher education institutes: The relationship between formulated official policies and grassroots initiatives. Teaching and Teacher Education, 42, 47-57. https://doi.org/10.1016/j.tate.2014.04.008

Pellicer, L. O., \& Anderson, L. W. (1995). A handbook for teacher leaders. Thousand Oaks, Ca: Corwin Press.

Penga, R. Z., \& Wu, W. P. (2016). Measuring intercultural contact and its effects on intercultural competence: A structural equation modeling approach. International Journal of Intercultural Relations, 53, 16-27. https://doi.org/10.1016/j.ijintrel.2016.05.003

Pitkänen, P., Verma, G., \& Kalekin-Fishman, D. (2002). Education and Immigration: Settlement policies and current practices. London: Routledge Falmer.

Rissanen, I., Kuusisto, E., \& Kuusisto, A. (2016). Developing teachers' intercultural sensitivity: Case study on a pilot course in Finnish teacher education. Teaching and Teacher Education, 59, 446-456. https://doi.org/10.1016/j.tate.2016.07.018

Sales, A., Traver, J. A., \& García, R. (2011). Action research as a school-based strategy in intercultural professional development for teachers. Teaching and Teacher Education, 27, 911-919. https://doi.org/10.1016/j.tate.2011.03.002

Schoorman, D., \& Bogotch, I. (2010). Conceptualisations of multicultural education among teachers: Implications for practice in universities and schools. Teaching and Teacher Education, 26, 1041-1048. https://doi.org/10.1016/j.tate.2009.10.047

Shapira-Lishchinsky, O. (2016). From ethical reasoning to teacher education for social justice. Teaching and Teacher Education. 60, 245-255. https://doi.org/10.1016/j.tate.2016.08.010

Xoxellis, P. (2002). Teacher training nowadays: International necessity - Greek developments and experiences. Proceedings of the 2nd International Conference on Education at the Dawn of the 21st Century. Patra: University of Patras. Retrieved from http://www.eriande.elemedu.upatras.gr/eriande/synedria/synedrio2/praktika/ksoxelis.htm (in Greek)

Yang, Y., \& Montgomery, D. (2013). Gaps or bridges in multicultural teacher education: A Q study of attitudes toward student diversity. Teaching and Teacher Education, 30, 27-37. https://doi.org/10.1016/j.tate.2012.10.003

Yuen, C. Y. M. (2010). Dimensions of diversity: Challenges to secondary school teachers with implications for intercultural teacher education. Teaching and Teacher Education, 26, 732-741.

https://doi.org/10.1016/j.tate.2009.10.009

This research did not receive any specific grant from funding agencies in the public, commercial, or not-for-profit sectors.

\section{Copyrights}

Copyright for this article is retained by the author(s), with first publication rights granted to the journal.

This is an open-access article distributed under the terms and conditions of the Creative Commons Attribution license (http://creativecommons.org/licenses/by/4.0/). 